(5) $=$

\title{
Pengaruh Penambahan Limestone terhadap Kuat Tekan Semen Portland Komposit
}

\author{
Irfan Purnawan dan Andi Prabowo \\ Program Studi Teknik Kimia, Fakultas Teknik, Universitas Muhammadiyah Jakarta \\ Jl Cempaka Putih Tengah 27 Jakarta Pusat, 10510, Telp. (021) 4256024, Fax. (021) 4256023 \\ *Alamat korespondensi: irfan.purnawan@umj.ac.id
}

(Submisi: 10 Desember 2017; Revisi: 19 Desember 2017; Penerimaan: 19 Desember 2017)

\begin{abstract}
A B S TRACT
Cement is the main component of construction that makes it an important commodity. Portland Composite Cement (PCC) is one of new cement variants that has similar characteristic to Portland Cement, but with better quality, more environmentally friendly and cheaper in price. The objective of this research is to understand the influence of limestone to the compressive strength of the cement and to determine the percentage of added limestone that gives maximum compressive strength to PCC. The variations of limestone addition to the cement were 0, 5, 10, 15, 20, and $25 \%$. The impact of added limestone was studied by several tests such as fineness test, residue test, chemical composition test and cement compressive strength. The result showed that the higher percentage of limestone added to the cement, the higher the result for residue test and fineness test, but lower result for compressive strength. The highest compressive strength obtained was at 2 days age while the best composition of the blended cement was $77 \%$ clinker, $15 \%$ limestone, $3 \%$ gypsum, and $5 \%$ blast furnace slag.
\end{abstract}

Keywords: cement, Portland composite cement, limestone, compressive strength, additives, clinker

\begin{abstract}
A B S T R A K
Semen merupakan bahan dasar utama konstruksi bangunan. Hal ini menjadikan semen merupakan komoditi yang strategis. Portland Composite Cement (PCC) merupakan jenis semen varian baru yang mempunyai sifat dan karakteristik hampir sama dengan semen Portland. Namun semen jenis PCC ini mempunyai kualitas yang lebih baik, ramah lingkungan, dan harga yang lebih ekonomis. Tujuan penelitian ini adalah mengetahui pengaruh penambahan limestone dengan berbagai variasi terhadap kuat tekan dan menentukan massa limestone yang dapat memberikan kuat tekan maksimum pada semen Portland komposit. Pembuatan semen Portland komposit dilakukan dengan penambahan limestone sebagai aditif. Variasi limestone yang ditambakan adalah 0, 5, 10, 15, 20, dan 25\%. Pengaruh penambahan limestone dapat diketahui dari hasil uji kehalusan, uji residu, uji komposisi kimia semen, dan uji kuat tekan semen. Hasil penelitian menunjukan bahwa semakin besar persentase pemakaian limestone di dalam blended cement maka nilai residu dan nilai kehalusan akan semakin besar namun nilai kuat tekan akan semakin rendah. Kuat tekan semen yang tertinggi yaitu nilai kuat
\end{abstract}


tekan pada umur 2 hari. Komposisi terbaik aditif limestone di dalam blended cement adalah 77\% clinker, $15 \%$ limestone, $3 \%$ gypsum, dan $5 \%$ blast furnace slag.

Kata kunci: semen, semen Portland komposit, limestone, kuat tekan, aditif, clinker

\section{Pendahuluan}

Semen merupakan salah satu bahan dasar utama konstruksi bangunan, sehingga menjadikan semen sebagai komoditi yang strategis. Saat ini total kapasitas produksi semen nasional mencapai 68,7 juta ton dengan kemampuan produksi 59,9 juta ton. Pada 2014, jumlah ekspor semen asal Indonesia hanya 220.000 ton sementara impor sebanyak 2,4 juta ton. Total kebutuhan semen nasional diperkirakan mencapai 62,4 juta ton (Kemenperin, 2016). Di Indonesia terdapat tujuh produsen semen yang beroperasi, yaitu Semen Gresik Group (SGG) yang menguasai sekitar $45 \%$, Indocement $30 \%$, Holcim Indonesia (15\%), dan lainnya sebesar $10 \%$ dibagi kepada Semen Andalas, Semen Baturaja, Semen Bosowa, dan Semen Kupang (Sunarsip, 2007). Dilihat dari penguasaan pasar tersebut, terdapat dua pelaku usaha yang mempunyai pangsa pasar sebagai market leader, yaitu SGG dan Indocement.

Pemenuhan kebutuhan pasar yang tinggi ditambah dengan kepekaan konsumen terhadap mutu, membuat produsen harus selalu menempatkan mutu sebagai target utama. Di sisi lain mutu produk harus ditunjang dengan proses yang prima. Tantangan yang dihadapi industri semen adalah mengurangi konsumsi energi dengan tetap menghasilkan produk yang bermutu tinggi. Jika dilihat tingkat kebutuhan energi final pada tahun 2015, sektor industri bisa dibagi menjadi 3 kelompok. Kelompok pertama sebagai kelompok pengguna energi tinggi adalah industri makanan dan minuman, pupuk kimia dan karet serta semen dan bukan logam dengan pangsa 59\%. Selanjutnya, kelompok pengguna energi menengah, yaitu industri tekstil dan barang kulit, pulp dan kertas, logam dasar besi dan baja, serta peralatan mesin dan transportasi dengan pangsa 39\%. Untuk kelompok pengguna energi rendah seperti kayu dan industri pengolahan lainnya memiliki pangsa sekitar 2\% (Dewan Energi Nasional, 2016).
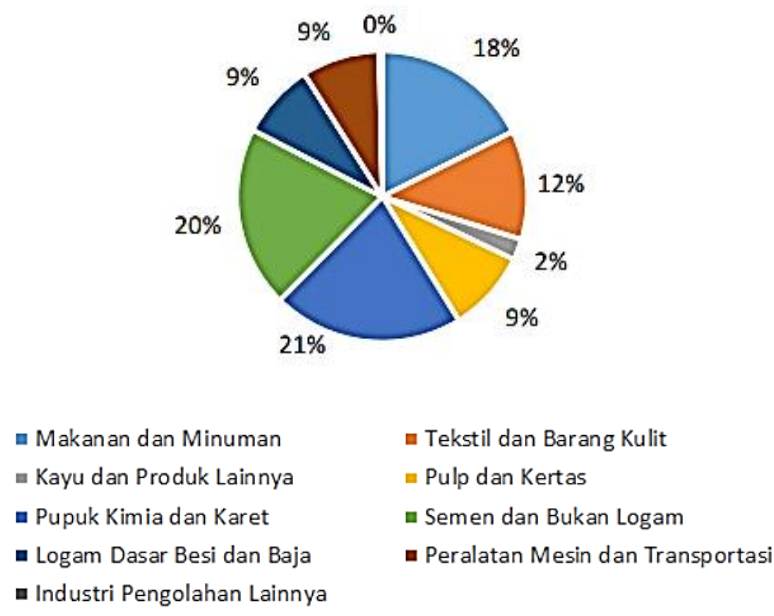

घ Tekstil dan Barang Kulit - Pulp dan Kertas

Gambar 1. Pangsa kebutuhan energi final menurut jenis industri tahun 2015

Tahun 2015, sesuai Gambar 1, kementrian ESDM mengelompokkan industri di Indonesia menjadi sembilan kategori. Dari kesembilan kategori tersebut, industri semen dan barang galian bukan logam menduduki peringkat kedua teratas sebagai industri yang mengonsumsi energi terbesar, yaitu $20 \%$, setelah industri logam dasar besi dan baja sebesar $21 \%$, itupun hanya selisih $1 \%$.

Semakin pesatnya perkembangan industri semen di Indonesia membuat muncul beberapa tipe semen antara lain Ordinary Portland Cement (OPC), White Cement, dan Portland Composite Cement (PCC). Semen PCC merupakan jenis semen varian lain yang mempunyai sifat dan karakteristik hampir sama dengan semen Portland, namun mempunyai kualitas yang lebih baik, ramah lingkungan dan harga yang lebih ekonomis. Komposisi bahan baku PCC adalah clinker, gypsum, dan zat tambahan lainnya (additive). Bahan aditif yang digunakan yaitu batu kapur (limestone), abu terbang (fly ash), dan trass. Trass merupakan hasil pelapukan endapan vulkanik, sebagian besar mengandung silika, 
besi, dan alumina dengan ikatan gugus oksida. Tidak seperti tipe OPC yang tidak menggunakan aditif fly ash dan trass, tipe PCC menggunakan tambahan zat aditif fly ash dan trass dengan senyawa $\mathrm{SiO}_{2}$ yang dapat meningkatkan kuat tekan. Bahan-bahan ini umumnya mengandung komponen silika amorf reaktif, yang pada reaksinya dengan air dan $\mathrm{Ca}(\mathrm{OH})_{2}$ akan membentuk senyawa kalsium silikat hidrat, disingkat CSH.

Senyawa CSH ini berupa gel yang akan terus terbentuk selama reaksi hidrasi dan akan mengisi pori di antara air dan semen yang belum terhidrasi. Karena volume air dan semen diasumsikan tetap, maka pada akhir reaksi hidrasi volume pori yang tersisa akan menjadi minimum. Hal ini yang menjadikan semen bersifat sebagai bahan pengikat (binder) yang mempunyai kekuatan mekanik. Karena bahan tambahan ini bereaksi dengan $\mathrm{Ca}(\mathrm{OH})_{2}$ dan membentuk $\mathrm{CSH}$, maka fraksi volume CSH akan lebih tinggi dan $\mathrm{Ca}(\mathrm{OH})_{2}$ lebih kecil dibandingkan pada semen Portland.

Selain adanya zat aditif fly ash dan trass, ditambahkan pula limestone yang berfungsi meningkatkan kuat tekan pada semen. Hal ini terjadi karena limestone mempunyai bentuk fisik yang mudah halus, sehingga dengan nilai kehalusan tersebut, limestone dapat menutup rongga-rongga yang terdapat di dalam semen sehingga bisa meningkatkan kuat tekan (Hariawan, 2007). Kehalusan semen akan mempengaruhi konsistensi normal dan waktu pengikatan. Semakin halus suatu semen maka semakin besar luas permukaannya, sehingga air yang diperlukan untuk mencapai konsistensi normal semakin tinggi. Reaksi hidrasi dan waktu pengikatan semakin cepat, serta panas hidrasi dan kuat tekan semakin tinggi, bila semen terlalu kasar maka kuat tekan, plastisitas, dan kestabilannya akan rendah (Vera dkk., 2000)

Pemakaian bahan tambahan sangat tergantung dari pengaruh positif terhadap sifat semen dan ketersediaan bahan yang dekat dengan lokasi produksi. Penelitian yang berkembang senantiasa diarahkan hasil akhir yaitu kuat tekan semen. Kuat tekan pada semen dipengaruhi oleh beberapa hal, diantaranya adalah jenis material yang ditambahkan, persentase penambahan material dan kecepatan reaksi hidrasi dari material.

Berdasarkan latar belakang yang dikaji, maka tujuan dalam penelitian ini adalah untuk: (1) mengetahui pengaruh penambahan limestone dengan berbagai variasi terhadap kuat tekan pada semen Portland komposit; (2) menentukan massa limestone yang dapat memberikan kuat tekan maksimum pada semen Portland komposit. Sedangkan hipotesis yang kami ambil adalah penambahan jumlah massa limestone akan mempengaruhi nilai kuat tekan yang signifikan pada semen Portland komposit, yaitu semakin besar jumlah massa limestone maka nilai kuat tekan semen akan semakin besar.

\section{Metode Penelitian}

\subsection{Bahan Penelitian}

Bahan yang digunakan dalam penelitian ini adalah limestone, clinker, gypsum dan air. Limestone yang digunakan memiliki kandungan $\mathrm{CaCO}_{3}$ dengan tes methylene blue dan kandungan material organik ketika dites dengan EN 136-9 tidak melebihi 20\%. Clinker sebagai bahan utama dalam pembuatan semen, merupakan hasil pembakaran dari batu kapus, clay dan bahan tambahan lainnya. gypsum berfungsi untuk memperlambat proses pengerasan pada semen.

\subsection{Cara Penelitian}

Penelitian dilakukan di laboratorium mengacu pada American Standard Testing Method (ASTM) C109 untuk uji compressive strength, ASTM C114 untuk uji analisis kimia, ASTM C204 dan ASTM C430 untuk uji kehalusan. Adapun tahapan-tahapan penelitian yang dilakukan adalah persiapan bahan uji dan pengujian bahan.

\subsubsection{Persiapan bahan uji (blended cement)}

a. Persiapan material, dilakukan pengambilan terak semen (clinker), gypsum, dan batu kapur (limestone), kemudian dilakukan pemanasan pada temperatur $100^{\circ} \mathrm{C}$ selama 24 jam di dalam oven pemanas. 
b. Penggilingan clinker

Clinker dihaluskan dengan digiling menggunakan tube mill (rotary mill). Penggilingan dilakukan dengan menggiling terlebih dahulu clinker hingga mencapai kehalusan sekitar $2000 \mathrm{~cm}^{2} / \mathrm{g}$, kemudian dilakukan pencampuran dengan gypsum dan limestone (dengan berbagai variasi komposisi), lalu penggilingan dilanjutkan hingga mencapai kehalusan $4000 \mathrm{~cm}^{2} / \mathrm{g}$. Penggilingan dilakukan dengan kecepatan 35 rpm selama 1 jam untuk tiap-tiap komposisi/variasi limestone $0,5,10,15,20$, dan $25 \%$ untuk menguji variabel pengaruh penambahan limestone. Selama proses penggilingan dilakukan pengamatan kehalusan material yang digiling dengan cara menghentikan sementara mill, mengambil sampel untuk diukur tingkat kehalusannya menggunakan Blaine meter.

Tabel 1. Variasi komposisi limestone

\begin{tabular}{cc}
\hline Kode Sampel & Variasi Limestone $(\%)$ \\
\hline $\mathrm{cm} 0$ & 0 \\
$\mathrm{~cm} \mathrm{1}$ & 5 \\
$\mathrm{~cm} 2$ & 10 \\
$\mathrm{~cm} \mathrm{3}$ & 15 \\
$\mathrm{~cm} 4$ & 20 \\
$\mathrm{~cm} \mathrm{5}$ & 25 \\
\hline
\end{tabular}

c. Setelah penggilingan selama 1 jam, rotary mill berhenti secara otomatis dan sampel dikeluarkan untuk pengujian lalu dimasukkan plastik dan diberi identitas.

d. Untuk keperluan pengujian kuat tekan dibuat mortar (campuran semen, pasir dan air) untuk pengujian pada $1,3,7$, dan 28 hari, yang masing masing dilakukan 3 kali.

\subsubsection{Pengujian bahan}

Analisis sampel semen pengujian yang dilakukan adalah uji kehalusan semen (Blaine), analisis residu $45 \mu \mathrm{m}$, komposisi kimia semen dan kuat tekan semen (compressive strength).

a. Uji kehalusan semen (Blaine)

Dalam pengujian ini, digunakan standar ASTM C 204 dengan spesifikasi air permeability apparatus, piringan logam, silinder, torak, tony blaine 1 set, kertas saring no. 40.

b. Uji Residu $45 \mu \mathrm{m}$ dengan Metode Alphine

Dalam pengujian ini, digunakan standar ASTM C 430 dengan spesifikasi balance, ayakan $45 \mu \mathrm{m}$, pesawat Hosokawa Alpine.

Perhitungan residu: Kadar Residu $=($ Berat Residu/Berat Sampel) x 100\%.

c. Uji Komposisi Kimia dengan XRF

Dalam pengujian ini, digunakan standar ASTM C-114-10.

d. Uji Kuat Tekan Semen (compressive strength) Dalam pengujian ini, digunakan standar ASTM C 109. alat yang digunakan adalah mixer mortar, bowl, paddle, pisau, caliper, flow table, container, tamper, cube mold, cabinet, tempat perendaman, toni teknik, kuas, dan lap. Bahan yang digunakan adalah semen, air, dan pasir.

\section{Hasil dan Pembahasan}

Pengujian semen yang dilakukan adalah uji kehalusan dan residu, komposisi kimia semen, dan kuat tekan semen. Pengujian dilakukan dengan menggunakan variasi komposisi limestone.

\subsection{Hasil Uji Kehalusan dan Residu}

Uji kehalusan dan residu dilakukan untuk mengetahui ukuran partikel dari semen. Semakin kecil ukuran partikelnya, maka residu yang tertinggal di saringan akan semakin sedikit dan menghasilkan nilai kehalusan yang tinggi. Proses hidrasi dari semen diawali dari permukaan partikel semen, semakin besar luas permukaan spesifik dari semen akan meningkatkan kecepatan hidrasi yang pada akhirnya mempercepat proses pengikatan dan pengerasan semen (Suprapto, 1995).

Hasil uji kehalusan dengan variasi komposisi limestone disajikan pada Tabel 2. Tabel 2 menunjukkan pengaruh nilai kehalusan semen dengan penambahan variasi komposisi limestone, semakin banyak penambahan limestone maka nilai kehalusan semen akan menjadi semakin tinggi. Kehalusan semen ini akan mempengaruhi konsistensi normal dan waktu pengikat. Semakin 
halus suatu semen maka semakin besar luas permukaannya, sehingga air yang diperlukan untuk mencapai konsistensi normal semakin tinggi. Reaksi hidrasi dan waktu pengikatan semakin cepat, serta panas hidrasi dan kuat tekan semakin tinggi. Bila semen terlalu kasar maka kuat tekan, plastisitas, dan kestabilannya akan rendah (Vera dkk., 2000).

Tabel 2. Data hasil uji kehalusan (Blaine)

\begin{tabular}{|c|c|c|c|}
\hline $\begin{array}{l}\text { Kode } \\
\text { Sampel }\end{array}$ & Pengulangan & $\begin{array}{c}\text { Variasi } \\
\text { Limestone }(\%)\end{array}$ & $\begin{array}{c}\text { Blaine } \\
\left(\mathrm{cm}^{2} / \mathrm{gr}\right)\end{array}$ \\
\hline \multirow{2}{*}{$\mathrm{cm} 0$} & 1 & \multirow[t]{2}{*}{ 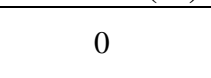 } & 4180 \\
\hline & 2 & & 4160 \\
\hline \multirow{4}{*}{$\mathrm{cm} 1$} & \multicolumn{2}{|c|}{ Rata-rata } & 4170 \\
\hline & 1 & \multirow{2}{*}{5} & 4430 \\
\hline & 2 & & 4410 \\
\hline & \multicolumn{2}{|c|}{ Rata-rata } & 4420 \\
\hline \multirow{3}{*}{$\mathrm{cm} 2$} & 1 & \multirow{2}{*}{10} & 4690 \\
\hline & 2 & & 4710 \\
\hline & \multicolumn{2}{|c|}{ Rata-rata } & 4700 \\
\hline \multirow{3}{*}{$\mathrm{cm} 3$} & 1 & \multirow{2}{*}{15} & 5090 \\
\hline & 3 & & 5130 \\
\hline & \multicolumn{2}{|c|}{ Rata-rata } & 5110 \\
\hline \multirow{2}{*}{$\mathrm{cm} 4$} & 1 & \multirow{2}{*}{20} & 5300 \\
\hline & 2 & & 5320 \\
\hline \multirow{4}{*}{$\mathrm{cm} 5$} & Rat & 1-rata & 5310 \\
\hline & 1 & \multirow{2}{*}{25} & 5560 \\
\hline & 2 & & 5540 \\
\hline & \multicolumn{2}{|c|}{ Rata-rata } & 5550 \\
\hline
\end{tabular}

Hasil uji residu dengan variasi komposisi limestone disajikan pada Tabel 3.

Tabel 3. Data hasil uji residu

\begin{tabular}{|c|c|c|c|}
\hline $\begin{array}{c}\text { Kode } \\
\text { sampel }\end{array}$ & Pengulangan & $\begin{array}{c}\text { Variasi } \\
\text { Limestone }(\%)\end{array}$ & $\begin{array}{c}\text { Residu } \\
(\%)\end{array}$ \\
\hline \multirow{2}{*}{$\mathrm{cm} 0$} & 1 & \multirow{2}{*}{ (2) } & 3,20 \\
\hline & 2 & & 3,00 \\
\hline \multirow{4}{*}{$\mathrm{cm} 1$} & \multicolumn{2}{|c|}{ Rata-rata } & 3,10 \\
\hline & 1 & \multirow{2}{*}{5} & 3,50 \\
\hline & 2 & & 3,60 \\
\hline & \multicolumn{2}{|c|}{ Rata-rata } & 3,55 \\
\hline \multirow{3}{*}{$\mathrm{cm} 2$} & 1 & \multirow{2}{*}{10} & 3,70 \\
\hline & 2 & & 3,80 \\
\hline & & a-rata & 3,75 \\
\hline \multirow{3}{*}{$\mathrm{cm} 3$} & 1 & \multirow{2}{*}{15} & 4,10 \\
\hline & 3 & & 4,30 \\
\hline & \multicolumn{2}{|c|}{ Rata-rata } & 4,20 \\
\hline \multirow{2}{*}{$\mathrm{cm} 4$} & 1 & \multirow{2}{*}{20} & 4,60 \\
\hline & 2 & & 4,60 \\
\hline \multirow{4}{*}{$\mathrm{cm} 5$} & & a-rata & 4,60 \\
\hline & 1 & \multirow{2}{*}{25} & 5,00 \\
\hline & 2 & & 5,20 \\
\hline & \multicolumn{2}{|c|}{ Rata-rata } & 5,10 \\
\hline
\end{tabular}

Tabel 3 menunjukkan pengaruh nilai residu semen dengan penambahan variasi komposisi limestone. Semakin banyak penambahan limestone maka nilai residu semen akan menjadi semakin tinggi. Uji residu dilakukan untuk menetukan kehalusan semen yang akan mempengaruhi konsistensi normal dan waktu pengikat. Prinsip dari uji residu adalah semakin kecil \% residu yang dihasilkan dari suatu produk maka partikel yang lolos semakin banyak.

\subsection{Komposisi Kimia Semen dengan XRF}

Komposisi kimia di dalam semen ditetapkan dengan menggunakan metode $X$-ray fluorescence (XRF). Komposisi kimia blended cement meliputi oksida logam seperti $\mathrm{SiO}_{2}, \mathrm{Al}_{2} \mathrm{O}_{3}, \mathrm{Fe}_{2} \mathrm{O}_{3}$, $\mathrm{CaO}, \mathrm{MgO}$, dan $\mathrm{SO}_{3}$. Penambahan aditif batu kapur yang ditambahkan pada blended cement.

Hasil analisis komposisi kimia menggunakan XRF dengan variasi komposisi limestone dapat dilihat pada Gambar 2.

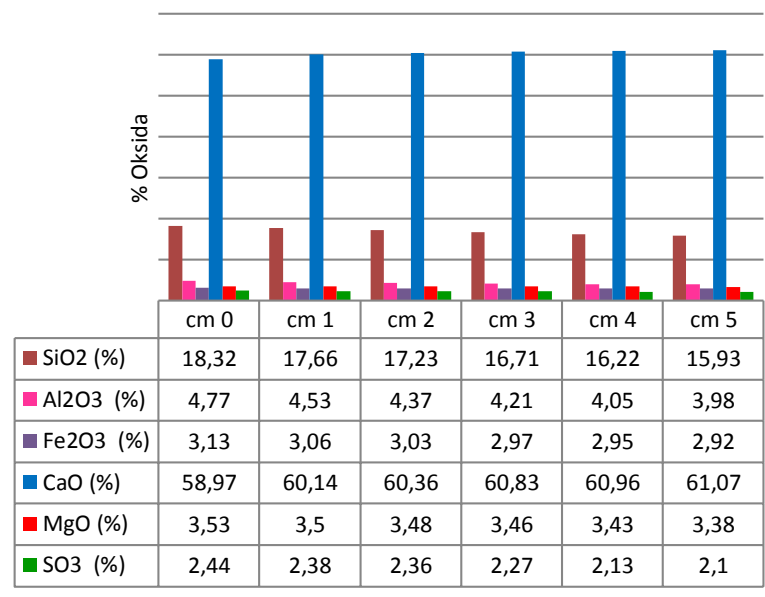

Gambar 2. Komposisi kimia semen yang dianalisis dengan XRF

Gambar 2 menunjukkan bahwa dengan semakin bertambahnya penambahan batu kapur di dalam semen maka berpengaruh terhadap komposisi kimia semen. Hasil penetapan komposisi kimia dengan menggunakan XRF memperlihatkan semakin tinggi penambahan aditif batu kapur pada blended cement, maka kadar $\mathrm{SiO}_{2}$ yang diperoleh semakin rendah. Hal ini disebabkan kandungan $\mathrm{SiO}_{2}$ merupakan senyawa kedua terbesar yang ada dalam semen setelah $\mathrm{CaO}$. Dalam semen, $\mathrm{SiO}_{2}$ selalu berikatan dengan oksida kalsium, baik sebagai C3S maupun sebagai C2S. Besarnya kadar $\mathrm{SiO}_{2}$ akan sangat mempengaruhi nilai silica modulus (SM). 
Jika kadar $\mathrm{SiO}_{2}$ rendah maka nilai $\mathrm{SM}$ yang dihasilkan pun rendah, jika kadar $\mathrm{SiO}_{2}$ tinggi maka nilai SM yang dihasilkan juga tinggi. Nilai silica modulus yang rendah akan mempengaruhi waktu pengikatan semen pendek dan kuat tekan awal semen pada umur 3-7 hari rendah. Penentuan kadar $\mathrm{SiO}_{2}$ tidak ada batasan khusus yang diberikan SNI 15-7064-2004.

Penambahan aditif batu kapur yang semakin besar pada blended cement akan menyebabkan kadar $\mathrm{Al}_{2} \mathrm{O}_{3}$ yang diperoleh semakin rendah. Hal ini disebabkan karena kandungan $\mathrm{Al}_{2} \mathrm{O}_{3}$ juga rendah. Besarnya kadar $\mathrm{Al}_{2} \mathrm{O}_{3}$ akan sangat mempengaruhi nilai alumina modulus (AM). Jika kadar rendah maka nilai AM yang dihasilkan pun rendah. Begitu pula sebaliknya, jika kadar $\mathrm{Al}_{2} \mathrm{O}_{3}$ tinggi maka nilai $\mathrm{AM}$ yang dihasilkan juga tinggi. Nilai AM yang rendah akan mempengaruhi kuat tekan awal semen rendah pada umur 3-7 hari. Penentuan kadar $\mathrm{Al}_{2} \mathrm{O}_{3}$ tidak ada batasan khusus yang diberikan SNI 15-70642004.

Penambahan aditif batu kapur yang semakin besar pada blended cement, maka kadar $\mathrm{Fe}_{2} \mathrm{O}_{3}$ yang diperoleh semakin rendah. Hal ini disebabkan karena pada semen, kandungan $\mathrm{Fe}_{2} \mathrm{O}_{3}$ juga rendah. Di samping itu $\mathrm{Al}_{2} \mathrm{O}_{3}, \mathrm{Fe}_{2} \mathrm{O}_{3}$, dan $\mathrm{CaO}$ akan membentuk senyawa kalsium alumina ferrit $\left(\mathrm{C}_{4} \mathrm{AF}\right)$ yang akan dapat mempengaruhi warna pada blended cement. Penentuan kadar $\mathrm{Al}_{2} \mathrm{O}_{3}$ tidak ada batasan khusus yang diberikan SNI 15-7064-2004, karena penentuan kadar $\mathrm{Fe}_{2} \mathrm{O}_{3}$ dimaksudkan untuk mencapai target semen yang akan diproduksi.

Penambahan aditif (limestone) yang semakin besar pada blended cement, maka kadar $\mathrm{CaO}$ yang diperoleh semakin tinggi. Hal ini disebabkan unsur terbanyak dari batu kapur adalah $\mathrm{CaCO}_{3}$ dengan kandungan $\mathrm{CaCO}_{3}$ di dalam limestone berkisar antara 80-99\%. Di samping itu juga merupakan senyawa yang bereaksi dengan senyawa silika, alumina, dan besi yang akan membentuk senyawa potensial penyusun utama semen yaitu C3S dan C2S. Penentuan kadar $\mathrm{CaO}$ tidak ada batasan khusus yang diberikan SNI 15-7064-2004. Penambahan aditif limestone yang semakin besar pada blended cement berpengaruh pada penurunan kadar $\mathrm{MgO}$.
$\mathrm{MgO}$ diperoleh dari peruraian (dekomposisi) dolomite, $\mathrm{CaCO}_{3}$, dan $\mathrm{MgCO}_{3}$ yang terdapat dalam batu kapur dan kandungan oksida logam $\mathrm{MgO}$ juga bisa berasal dari mineral-mineral tanah liat. Standar SNI 15-7064-2004 untuk kadar $\mathrm{MgO}$ adalah maksimum $6.0 \%$. Kadar $\mathrm{MgO}$ yang terlalu tinggi di dalam semen pada efek jangka panjang menyebabkan semen mengalami ekspansi sehingga dapat menimbulkan kerusakan pada konstruksi bangunan. Selain itu juga menyebabkan kualitas semen menurun.

Gypsum ditambahkan dalam semen bertujuan untuk mengatur pengikatan semen selama proses hidrasi berlangsung (sebagai retarder). Pada hidrasi semen C3A segera bereaksi dengan air membentuk $3 \mathrm{CaO} \cdot \mathrm{Al}_{2} \mathrm{O}_{3} 3 \mathrm{H}_{2} \mathrm{O}$ senyawa ini bereaksi dengan air membentuk ettringite. Namun bila terlalu banyak gypsum akan menimbulkan kerugian pada sifat ekspansi (keretakan semen) dan menurunkan kuat tekan. Penambahan aditif (limestone) yang meningkat pada blended cement berpengaruh pada penurunan kadar $\mathrm{SO}_{3}$. Batas maksimum yang ditentukan oleh SNI 15-7064-2004 adalah maksimum $4,0 \%$. Tingginya kadar $\mathrm{SO}_{3}$ di dalam semen terjadi karena kadar $\mathrm{SO}_{3}$ di dalam clinker terlalu tinggi sebesar $1,17 \%$ sehingga $\mathrm{SO}_{3}$ yang seharusnya hanya disumbangkan oleh gypsum dapat tambahan dari clinker dan clinker merupakan komponen utama dalam semen. Tingginya kandungan $\mathrm{SO}_{3}$ dalam clinker diakibatkan adanya sirkulasi dalam proses pembakaran di dalam tanur putar.

\subsection{Kuat Tekan Semen (Compressive Strength)}

Kuat tekan dapat diartikan sebagai kemampuan suatu material menahan suatu beban tekan. Kuat tekan merupakan sifat yang paling penting bagi semen. Perbedaan kuat tekan semen dapat dilihat dari komposisi mineral, kandungan kapur bebas, magnesium, kandungan gypsum, temperatur, perbandingan air dengan semen, kualitas agregat, cara pengerjaan, dan perlakuan. Kecepatan pengembangan kuat tekan semen sangat dipengaruhi oleh komposisi kimia mineral semen yang ada, seperti telah kita ketahui bahwa semen mengandung 4 mineral utama yaitu C3S, $\mathrm{C} 2 \mathrm{~S}$, C3A, dan C4AF yang mempunyai 
reaktifitas masing-masing berbeda sewaktu bertemu dengan air (Suprapto, 1995).

Dari hasil penelitian kuat tekan diperoleh hubungan nilai kuat tekan terhadap nilai residu dan kehalusan semen, hal ini ditunjukkan pada Tabel 4.

Tabel 4. Data hasil uji kuat tekan semen

\begin{tabular}{|c|c|c|c|c|c|c|}
\hline \multirow{2}{*}{$\begin{array}{l}\text { Kode } \\
\text { sampel }\end{array}$} & \multirow{2}{*}{ Pengulangan $L$} & \multirow{2}{*}{$\begin{array}{l}\text { Variasi } \\
\text { Limestone } \\
(\%)\end{array}$} & \multicolumn{4}{|c|}{ Compressive Strength $\left(\mathrm{kg} / \mathrm{cm}^{2}\right)$} \\
\hline & & & 1 hari & 3 hari & 7 hari & 28 hari \\
\hline \multirow{3}{*}{$\mathrm{cm} 0$} & 1 & \multirow{3}{*}{0} & 181,5 & 284,4 & 350,0 & 460,0 \\
\hline & 2 & & 180,3 & 285,7 & 351,7 & 462,4 \\
\hline & 3 & & 182,3 & 284,0 & 350,8 & 464,8 \\
\hline \multirow{5}{*}{$\mathrm{cm} 1$} & Rata-rat & & 181,4 & 284,7 & 350,8 & 462,4 \\
\hline & 1 & \multirow{3}{*}{5} & 168,3 & 279,4 & 332,5 & 450,3 \\
\hline & 2 & & 170,0 & 280,9 & 333,4 & 448,4 \\
\hline & 3 & & 168,4 & 280,2 & 336,7 & 458,9 \\
\hline & \multicolumn{2}{|c|}{ Rata-rata } & 168,9 & 280,2 & 334,2 & 452,5 \\
\hline \multirow{3}{*}{$\mathrm{cm} 2$} & 1 & \multirow{3}{*}{10} & 154,2 & 268,7 & 325,2 & 440,9 \\
\hline & 2 & & 156,5 & 268,2 & 324,4 & 442,5 \\
\hline & 3 & & 156,2 & 267,8 & 325,5 & 441,8 \\
\hline \multirow{5}{*}{$\mathrm{cm} 3$} & Rata-rat & & 155,6 & 268,2 & 325,0 & 441,7 \\
\hline & 1 & \multirow{3}{*}{15} & 142,5 & 250,7 & 298,6 & 395,6 \\
\hline & 2 & & 143,5 & 253,7 & 299,6 & 395,9 \\
\hline & 3 & & 140,8 & 251,6 & 298,8 & 393,5 \\
\hline & \multicolumn{2}{|c|}{ Rata-rata } & 142,3 & 252,0 & 299,0 & 395,0 \\
\hline \multirow{3}{*}{$\mathrm{cm} 4$} & 1 & \multirow{3}{*}{20} & 133,4 & 228,5 & 267,8 & 370,4 \\
\hline & 2 & & 130,8 & 226,7 & 267,4 & 371,4 \\
\hline & 3 & & 130,5 & 228,2 & 265,6 & 372,2 \\
\hline \multirow{5}{*}{$\mathrm{cm} 5$} & Rata-rat & & 131,6 & 227,8 & 266,9 & 371,3 \\
\hline & 1 & \multirow{3}{*}{25} & 120,4 & 210,2 & 249,5 & 353,4 \\
\hline & 2 & & 124,5 & 212,1 & 250,8 & 350,2 \\
\hline & 3 & & 122,4 & 212,9 & 252,6 & 352,8 \\
\hline & \multicolumn{2}{|c|}{ Rata-rata } & 122,4 & 211,7 & 251,0 & 352,1 \\
\hline
\end{tabular}

Tabel 4 menunjukkan bahwa penambahan komposisi optimum aditif limestone yaitu 15\%, karena dengan penambahan batu kapur di atas 15\% kekuatan tekannya berada di bawah spesifikasi yaitu pada umur 7 hari dan 28 hari menurut persyaratan SNI 15-7064-2004 minimal kuat tekan $290 \mathrm{~kg} / \mathrm{cm}^{2}$ dan $380 \mathrm{~kg} / \mathrm{cm}^{2}$. Tabel 4 juga menunjukkan bahwa semakin halus ukuran partikel semen maka kecepatan reaksi hidrasi bertambah cepat, karena luas permukaannya akan lebih besar dan reaksi dengan air akan cepat. Reaksi hidrasi adalah reaksi pengikatan kemudian disusul dengan reaksi pengerasan, dengan kata lain semakin halus semen maka semakin cepat reaksi hidrasi. Semakin cepat reaksi hidrasi maka reaksi pengikatan dan pengerasan berlangsung dengan cepat pula.

Penambahan limestone ke dalam semen memberikan pengaruh terhadap kekuatan semen, nilai kehalusan, dan nilai residu. Semakin besar persentase penambahan limestone maka kuat tekan semen semakin rendah. Nilai kehalusan semen semakin rendah dan nilai residu semen semakin tinggi. Limestone mempunyai sifat lunak maka ketika digiling berasama dengan clinker, kehalusan limestone akan lebih besar, karena ukuran partikelnya kecil maka limestone dapat mengisi rongga di dalam mortar yang pengaruhnya terhadap kekuatan tekan. Akan tetapi, semakin banyak penambahan limestone ke dalam semen tidak berarti kuat tekannya juga bertambah, karena dengan bertambahnya limestone maka clinker yang digunakan menjadi berkurang, sedangkan yang menyumbangkan kuat tekan semen yaitu senyawa potensial yang terdapat di dalam clinker seperti C3S, C2S, C3A, dan C4AF (Suprapto, 1995).

\section{Kesimpulan}

Berdasarkan hasil penelitian pada semen protland dengan berbagai variasi komposisi limestone, dapat disimpulkan bahwa:

1. Hasil analisis sifat fisika dan kimia menunjukan bahwa semakin besar persentase pemakaian limestone di dalam blended cement maka nilai residu dan nilai kehalusan akan semakin besar dan nilai kuat tekan akan semakin rendah.

2. Berdasarkan data analisis komposisi kimia seman menunjukkan bahwa pengaruh penambahan aditif limestone terhadap kualitas komposisi kimia blended cement yaitu semakin banyak aditif limestone yang ditambahkan pada blended cement maka kualitas komposisi kimia blended cement semakin rendah.

3. Berdasarkan analisis kuat tekan semen, kuat tekan semen yang baik apabila nilai kuat tekan selama 1 hari, 3 hari, 7 hari, dan 28 hari semakin meningkat. Berdasarkan hasil penelitian, didapat harga kuat tekan semen yang tertinggi yaitu nilai kuat tekan pada umur 2 hari.

4. Komposisi optimum aditif limestone di dalam blended cement adalah $77 \%$ clinker, $15 \%$ limestone, $3 \%$ gypsum, dan $5 \%$ blast furnace slag. 


\section{Daftar Pustaka}

ASTM C109, 1996, Test Method for Compressive Strength of Hydraulic Cement Mortars, Annual Book of ASTM Standard Section 4, ASTM International, United States of America.

ASTM C114, 1996, Standard Test Method for Chemical Analysis, Annual Book of ASTM Standard Section 4, ASTM International, United States of America.

ASTM C204-96, 1996. Test Method for Fineness of Hydraulic Cement by Air Permeability Apparatus. Annual Book of ASTM Standard Section 4, ASTM International, United States of America

ASTM C430, 1996, Standard Test Method for Fineness of Hydraulic Cement by the $45 \mu \mathrm{m}$ (no 325) Sieve, Annual Book of ASTM Standard Section 4, ASTM International, United States of America

Azwir, H. dan Turiyono M., 1992, Kualitas Raw Mix dan Clinker, PT. Indocement Tunggal Prakasa, Tbk. Cituereup, Bogor.

Dewan Energi Nasional, 2016. Indonesia Energy Outlook 2016, Sekretariat Jenderal Dewan Energi Nasional. http://www.den.go.id/index.php/publikasi/ind ex/EnergyOutlook, diakses 13 Desember 2017

Duda, W. H., 1985, Cement Data Book International Process Engineering in the Cement Industry Edisi 3. Bauverlag $\mathrm{GmbH}$. Weisbaden and Berum, Mc Donald and Evan, London.

Hariawan, J.B., 2012, Pengaruh Perbedaan Karakteristik Type Semen Ordinary Portland Cement (OPC) dan Portland Composite Cement (PCC) terhadap Kuat Tekan Mortar, Universitas Gunadarma, Depok.
Kementerian Perindustrian, 2016, Pasokan Semen Nasional 102 Juta Ton pada 2017, http://www.kemenperin.go.id/artikel/12223/pa sokan-semen-Nasional-102-juta-ton-pada2017, diakses 13 Desember 2017

Lea, F.M. and Desch, C.H., 1976, The Chemical of Cement and Concrete $2^{\text {nd }}$ Edition. Edward Arnold, Ltd., London.

Perry, R.H, 1984, Chemical Engineer's Handbook Edisi 6, Mc Graw-Hill, New York.

Roosyanto, S., 1992, Instrumentasi, Industrial Relation Division Training and Development Departemen, Citeureup.

SNI 15-2049-1994, 1994, Mutu dan Cara Uji Semen Portland, Badan Standarisasi Nasional, Jakarta.

SNI 15-7064-2004, 2004, Semen Portland Komposit, Badan Standarisasi Nasional, Jakarta.

Suprapto, B.B., 1995, Teknologi Semen, Industrial Relation Division Training and Development Departement, Citeureup.

Sunarsip, 2007, Situasi Industri Semen Nasional dan Antisipasinya, Harian Investor Daily. p. 4

Vera, Roosyanto, dan Erry, 2000, Semen Portland Bahan Baku Sifat-Sifat dan Pengujian. Industrial Relation Division Training and Development Departement, Citeureup. 